Article

\title{
Coupling Persulfate-Based AOPs: A Novel Approach for Piroxicam Degradation in Aqueous Matrices
}

\author{
Antonios Stathoulopoulos ${ }^{1}[$, Dionissios Mantzavinos $1, *(1)$ and Zacharias Frontistis $2, *$ (i) \\ 1 Department of Chemical Engineering, University of Patras, Caratheodory 1, University Campus, \\ GR-26504 Patras, Greece; stathant22@gmail.com \\ 2 Department of Chemical Engineering, University of Western Macedonia, GR-50100 Kozani, Greece \\ * Correspondence: mantzavinos@chemeng.upatras.gr (D.M.); zfrontistis@uowm.gr (Z.F.); \\ Tel.: +30-261-099-6136 (D.M.)
}

Received: 4 May 2020; Accepted: 26 May 2020; Published: 27 May 2020

\begin{abstract}
The activated persulfate degradation of piroxicam, a non-steroidal anti-inflammatory drug (NSAID) belonging to oxicams, was investigated. Persulfate was activated with thermal energy or (UV-A and simulated solar) irradiation. Using $250 \mathrm{mg} / \mathrm{L}$ sodium persulfate at $40{ }^{\circ} \mathrm{C}$ degraded almost completely $0.5 \mathrm{mg} / \mathrm{L}$ of piroxicam in $30 \mathrm{~min}$. Increasing piroxicam concentration from 0.5 to $4.5 \mathrm{mg} / \mathrm{L}$ decreased its removal. The observed kinetic constant was increased almost ten times from 0.077 to $0.755 \mathrm{~min}^{-1}$, when the temperature was increased from 40 to $60{ }^{\circ} \mathrm{C}$, respectively. Process efficiency was enhanced at $\mathrm{pH} 5-7$. At ambient conditions and $30 \mathrm{~min}$ of irradiation, $94.1 \%$ and $89.8 \%$ of $0.5 \mathrm{mg} / \mathrm{L}$ piroxicam was removed using UV-A LED or simulated solar radiation, respectively. Interestingly, the use of simulated sunlight was advantageous over UV-A light for both secondary effluent, and $20 \mathrm{mg} / \mathrm{L}$ of humic acid solution. Unlike other advanced oxidation processes, the presence of bicarbonate or chloride in the range $50-250 \mathrm{mg} / \mathrm{L}$ enhanced the degradation rate, while the presence of humic acid delayed the removal of piroxicam. The use of 0.5 and $10 \mathrm{~g} / \mathrm{L}$ of methanol or tert-butanol as radical scavengers inhibited the reaction. The coupling of thermal and light activation methods in different aqueous matrices showed a high level of synergy. The synergy factor was calculated as $68.4 \%$ and $58.4 \%$ for thermal activation $\left(40^{\circ} \mathrm{C}\right)$ coupled with either solar light in $20 \mathrm{mg} / \mathrm{L}$ of humic acid or UV-A LED light in secondary effluent, respectively.
\end{abstract}

Keywords: piroxicam; AOPs; synergy; persulfate; coupling AOPs; wastewater treatment; NSAIDs; sulfate radicals; LED

\section{Introduction}

In recent decades, the emergence of micropollutants in the water cycle has become a global issue of environmental concern. These emerging harmful substances are naturally occurring compounds, as well as synthetic compounds such as pharmaceuticals, steroids, chemicals, pesticides, and others [1].

Nowadays, pharmaceuticals are attracting more and more interest because they affect the quality of drinking water, ecosystems, and can pose a risk to human life [2]. Pharmaceutical compounds are detected mainly in urban wastewater [3], wastewater treatment plants (WWTPs) [4,5], hospital effluents and in the agricultural sector [6-8], while their concentration ranges from a few $\mathrm{ng} / \mathrm{L}$ to several $\mu \mathrm{g} / \mathrm{L}$ [9-11]. Despite their low concentration, they are resistant to biological degradation because conventional WWTPs cannot achieve high rates of removal of micropollutants $[12,13]$. Thus, they pose a threat to humans and animals that lead to the accumulation of flora and fauna of the local ecosystem [14-17].

Among different pharmaceutical compounds, non-steroidal anti-inflammatory drugs (NSAIDs) constitute a large group consumed by a large portion of the population. One of the most popular 
NSAIDs is piroxicam (PIR), a substance belonging to the family of oxicams. It is widely used to treat and relieve pain under swelling conditions such as osteoarthritis [18], and it is detected in various environmental matrices $[19,20]$.

Due to the inadequate treatment of pharmaceuticals in conventional WWTPs, it is essential to research and develop new processes that can be applied to existing WWTPs to increase their efficacy and remove persistent pollutants. Advanced oxidation processes (AOPs) are oxidation technologies applied usually but not exclusively to the aqueous phase, and they are based on the production of reactive oxygen species (ROS), such as hydroxyl radicals, using an oxidizing agent or external energy. ROS react with the target pollutant by converting it into a less harmful compound in comparison with the original compound or even to carbon dioxide [21].

A new type of oxidizing agent has sparked the interest of researchers during recent years. Sodium persulfate (SPS) $\left(\mathrm{Na}_{2} \mathrm{~S}_{2} \mathrm{O}_{8}\right)$ is highly stable at room temperature, has a high solubility, moderate cost, non-selective character and it is solid at ambient temperatures making it easy to store and transport [22-24]. Moreover, upon activation, the main radical product, sulfate radical, has a higher lifespan and selectivity in comparison with hydroxyl radicals. [25]. Nevertheless, SPS should be activated to increase the degree of removal of the pollutant due to low oxidation potential $(\mathrm{E}=2.01 \mathrm{~V})[22]$. The benefit of using SPS is that it can be activated by different factors such as heat, ultraviolet (UV) radiation, ultrasounds, presence of transition metals, and even carbon-based materials like graphene and biochars [26-28].

In a recent work, Frontistis [29] examined the decomposition of piroxicam (PIR) under UV-C/SPS process [29]. It was found that the presence of oxidant reduced the treatment time for the decomposition of $1 \mathrm{mg} / \mathrm{L}$ PIR in pure water from $20 \mathrm{~min}$ to $4 \mathrm{~min}$. However, the observed kinetic constant decreased approximately 14 times, i.e., from 0.55 to $0.04 \mathrm{~min}^{-1}$ from ultrapure to secondary effluent. The same behavior was observed in the case of iron-activated persulfate [30], where in the presence of organics the kinetic constant decreased from 0.15 to $0.07 \mathrm{~min}^{-1}$. Recently, Ioannidi et al. [31] demonstrated that even UV-A light could activate persulfate and degrade the endocrine disruptor propyl paraben. Light emitted diodes (LED) can be used as the light source, thus providing a green approach compared to conventional low or medium pressure UV-C lamps, while the use of solar light that contains almost 5-7\% of UV-A radiation may become a viable option.

As a continuation, this work focused on the removal of piroxicam using heat- and (UV-A or simulated solar) light-activated persulfate with particular emphasis on the degree of synergy between the two methods to achieve higher drug degradation rates and to avoid disadvantages associated with the use of (i) homogeneous Fenton process (i.e., iron precipitation and the need for separation and neutralization) and/or (ii) UV-C lamps (low water transmittance, high energy demand and presence of mercury). The effect of several operating parameters such as SPS concentration, $\mathrm{pH}$, temperature, type of irradiation, and the use of different water matrices was evaluated.

\section{Materials and Methods}

\subsection{Chemicals}

Piroxicam (PIR, $\mathrm{C}_{15} \mathrm{H}_{13} \mathrm{~N}_{3} \mathrm{O}_{4} \mathrm{~S}$, CAS number 36322-90-4), and sodium persulfate (SPS, $\mathrm{Na}_{2} \mathrm{~S}_{2} \mathrm{O}_{8}$, CAS number 7775-27-1) were purchased from Sigma-Aldrich (Darmstadt, Germany). Sodium chloride ( $\mathrm{NaCl}, \mathrm{CAS}$ number 7647-14-5), sodium bicarbonate (BIC, $\mathrm{NaHCO}_{3}, \mathrm{CAS}$ number 144-55-8), methanol $\left(\mathrm{CH}_{3} \mathrm{OH}\right.$, CAS number 67-56-1), tert-butanol $\left(\left(\mathrm{CH}_{3}\right)_{3} \mathrm{COH}\right.$, CAS number 75-65-0) and humic acid (HA, CAS number 1415-93-6) were also supplied from Sigma-Aldrich.

\subsection{Water Matrices}

Two different water matrices were used to evaluate the removal of piroxicam. More specifically, (i) ultrapure water (UPW): conductivity $=0.061 \mathrm{mS} / \mathrm{cm}, \mathrm{pH}=6$ obtained from a purification system (EASY-pureRF-Barnstead/Thermolyne, Waltham, MA, USA); (ii) secondary treated effluent taken from 
the University of Patras treatment plant (WW): $\mathrm{pH}=8$, conductivity $=815 \mathrm{mS} / \mathrm{cm}$, alkalinity $=182 \mathrm{mg} / \mathrm{L}$, chemical oxygen demand $=21 \mathrm{mg} / \mathrm{L}$, total organic carbon $=7 \mathrm{mg} / \mathrm{L}$, total suspended solids $=1.8 \mathrm{mg} / \mathrm{L}$, chloride $=79 \mathrm{mg} / \mathrm{L}$, sulfate $=28 \mathrm{mg} / \mathrm{L}$ and nitrate $=5.8 \mathrm{mg} / \mathrm{L}$. Besides these matrices, UPW was added $\mathrm{HA}, \mathrm{BIC}$ or $\mathrm{NaCl}$ to assess the effect of organic and inorganic ions on the removal of piroxicam.

\subsection{Heat Activated Persulfate Experiments}

Initially, a fresh stock of $19 \mathrm{mg} / \mathrm{L}$ PIR was prepared and then diluted to the desired concentration. Two hundred $\mathrm{mL}$ of an aqueous solution containing the desired amount of PIR was mixed with the appropriate water matrix and then poured into a glass, double-layered, cylindrical vessel that was open to the atmosphere (open-air equilibrium). The reactor was mounted on a magnetic stirrer to achieve homogenous mixing throughout the conduction of the experiment. To control the temperature, the reactor was connected to a thermostatic bath (Grant LFV6, Grant Instruments Ltd., Royston, UK). When the temperature reached the required value $\left(25-60^{\circ} \mathrm{C}\right)$, the desired amount of SPS was added, and the reaction began. About $1.2 \mathrm{~mL}$ of the reaction mixture was periodically withdrawn from the reactor, quenched with $0.3 \mathrm{~mL}$ of methanol, filtered with a $0.22 \mathrm{~mm}$ PVDF syringe filter and analyzed using high performance liquid chromatography (HPLC). Most of the experiments were performed in duplicate and mean values are quoted as results, whose deviation never exceeded $5 \%$.

\subsection{Light Activated Persulfate Experiments}

Two types of radiation sources were used to simulate ultraviolet and solar light, specifically (i) a 10 W LED lamp that emits predominantly at $365( \pm 5) \mathrm{nm}(\mathrm{UV}-\mathrm{A})$, (ii) a solar simulator (Newport, model LCS-100, Irvine, CA. USA) equipped with a $100 \mathrm{~W}$ xenon, ozone-free lamp and an AM1.5G filter (Newport, Irvine, CA. USA). By means of chemical actinometry, the photon flux in the UV-A part of the spectrum was measured and found equal to $11.3 \mathrm{~W} / \mathrm{m}^{2}$ for the UV-A LED lamp and $10.5 \mathrm{~W} / \mathrm{m}^{2}$ for the solar simulator. Both lamps were left to warm up for $10 \mathrm{~min}$ prior to the beginning of the experiment.

\subsection{High Performance Liquid Chromatography}

High performance liquid chromatography (HPLC Aliance 2695, Waters, Milford, MA, USA) was employed to monitor the concentration of piroxicam. The separation was achieved on a Kinetex XB-C18 $100 \mathrm{~A}$ column $(2.6 \mu \mathrm{m}, 2.1 \mathrm{~mm} \times 150 \mathrm{~mm})$ and a $0.5 \mu \mathrm{m}$ inline filter (Krudkatcher Ultra) both purchased from Phenomenex (Torrance, CA, USA). The mobile phase, consisting of 75:25 UPW: acetonitrile, eluted isocratically at $0.25 \mathrm{~mL} / \mathrm{min}$ and $45^{\circ} \mathrm{C}$. Detection was achieved through a photodiode array detector (Waters 2996 PDA) in which the detection wavelength was set at $360 \mathrm{~nm}$, and the analysis of each sample lasted for $10 \mathrm{~min}[29,30]$. The limit of detection was $3.52 \mu \mathrm{g} / \mathrm{L}$ and the limit of quantitation was $11.75 \mu \mathrm{g} / \mathrm{L}$.

\subsection{Process Synergy}

Usually, the simultaneous application of two or more advanced oxidation processes can help reduce the amount of harmful substances due to the increased production of reactive species. The percentage of synergy (S) is the normalized difference between the kinetic constant of the combined process $\left(\mathrm{k}_{\text {combined }}\right)$ and the sum of the individual processes $\mathrm{k}_{\mathrm{i}}$, as shown below [32]:

$$
\begin{gathered}
\mathrm{S}=\frac{\mathrm{k}_{\text {combined }}-\sum_{1}^{\mathrm{n}} \mathrm{k}_{\mathrm{i}}}{\mathrm{k}_{\text {combined }}} \times 100(\%) \\
\text { where } \mathrm{S}\left\{\begin{array}{l}
>0, \text { synergistic effect } \\
=0, \text { cumulative effect } \\
<0, \text { competitive effect }
\end{array}\right.
\end{gathered}
$$


In the present study, emphasis was placed on coupling thermal activation with either radiation source (UV-A LED lamp) or simulated solar light, in different water matrices, to evaluate the degree of PIR removal. In this respect, Equation (1) is re-arranged as follows:

$$
\mathrm{S}=\frac{\mathrm{k}_{\text {combined }}-\mathrm{k}_{\text {heat-activated SPS }}-\mathrm{k}_{\text {light-activated SPS }}}{\mathrm{k}_{\text {combined }}} \times 100(\%)
$$

where $\mathrm{k}_{\text {heat-activated SPS }}$ is the constant of thermal activation and $\mathrm{k}_{\text {light-activated SPS }}$ is the constant of either light activation.

In addition to the definition of synergy shown in Equation (1), one can also define the percentage of enhancement (E), as follows [33]:

$$
\mathrm{E}=\frac{\mathrm{k}_{\text {combined }}-\mathrm{k}_{\text {heat-activated SPS }}}{\mathrm{k}_{\text {combined }}} \times 100(\%)
$$

\section{Results}

\subsection{Effect of SPS Concentration}

Initially, a series of experiments were conducted to test the effect of oxidant on the degradation of piroxicam under mild temperature $\left(40^{\circ} \mathrm{C}\right)$, as shown in Figure 1.

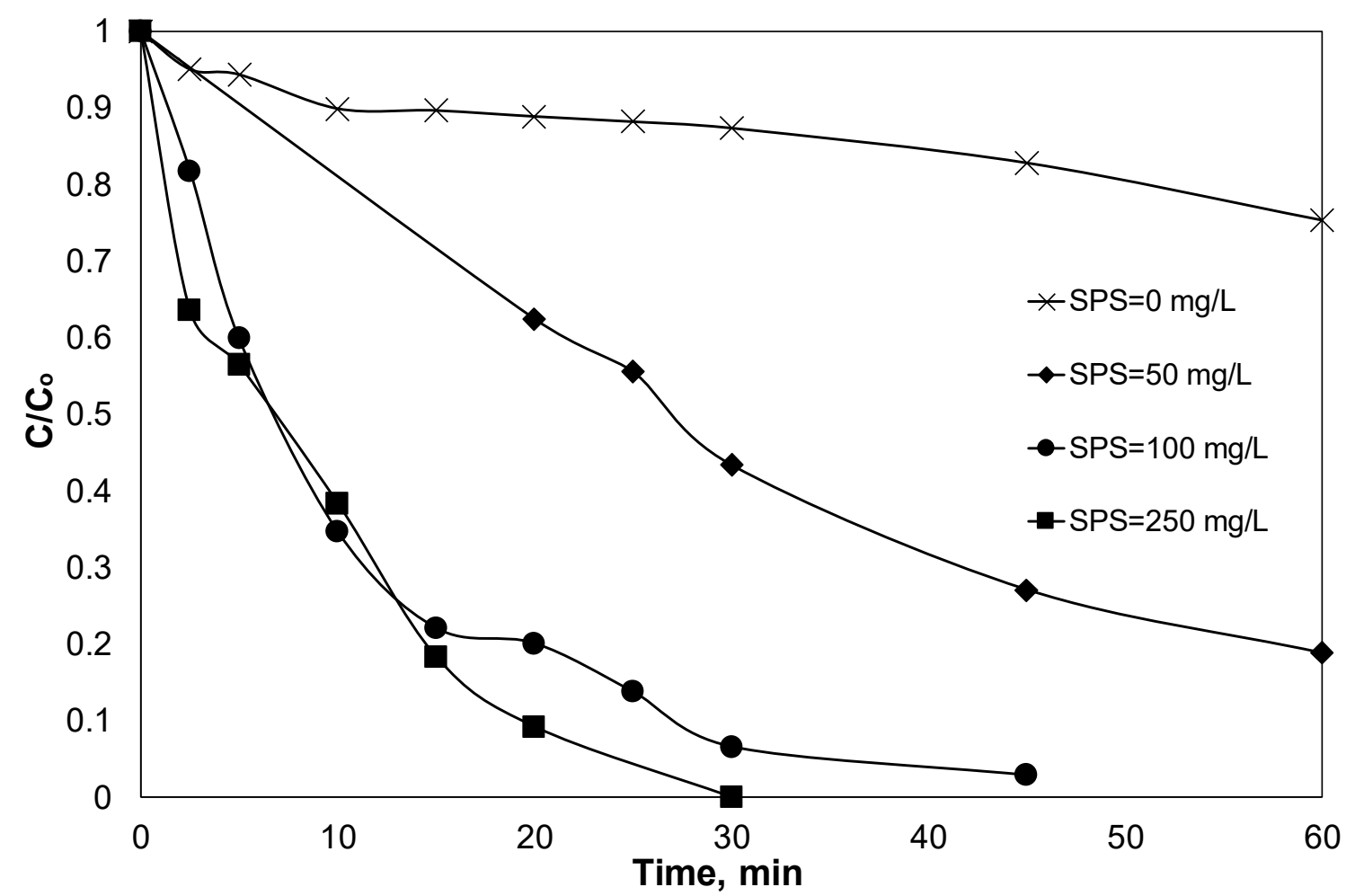

Figure 1. Effect of sodium persulfate (SPS) concentration on $0.5 \mathrm{mg} / \mathrm{L}$ prioxicam (PIR) degradation at $40{ }^{\circ} \mathrm{C}$ in ultrapure water (UPW) and inherent $\mathrm{pH}$.

Thermolysis (i.e., in the absence of SPS) results in only about $25 \%$ PIR degradation after 60 min at $40{ }^{\circ} \mathrm{C}$, therefore the direct thermal degradation is not a viable option and the implementation of AOPs is essential. The addition of SPS enhances PIR degradation, which is favored at higher oxidant concentrations in agreement with previous studies [34,35]. Complete PIR removal can be achieved after $30 \mathrm{~min}$ using $250 \mathrm{mg} / \mathrm{L} \mathrm{SPS}$, while at the same time $55 \%$ removal is recorded at $50 \mathrm{mg} / \mathrm{L} \mathrm{SPS}$.

Excessive use of SPS should be avoided because self-scavenging reactions may occur, resulting in decreased performance of the process [36,37]. However, this phenomenon was not observed during 
this study, most likely due to the low amount of oxidant. The cost of the whole process is affected by the amount of oxidizing agent. Moreover, large quantities of persulfate generate high amounts of sulfate ions that are classified as pollutants at high concentrations. Bearing in mind that optimization was not the goal of this work, all subsequent experiments were performed at a concentration less or equal to $250 \mathrm{mg} / \mathrm{L}[30,36,37]$.

\subsection{Effect of the Initial Concentration of Piroxicam}

Since NSAIDs are detected in a range of low concentrations in environmental matrices, it is crucial to investigate the effect of their initial concentration on process efficiency. For this reason, another set of experiments were performed at $50{ }^{\circ} \mathrm{C}$ and four different initial concentrations of piroxicam between 0.5 and $4.5 \mathrm{mg} / \mathrm{L}$ and the results are shown in Figure 2. As clearly shown, longer oxidation times are needed for the complete PIR degradation at higher initial concentrations.

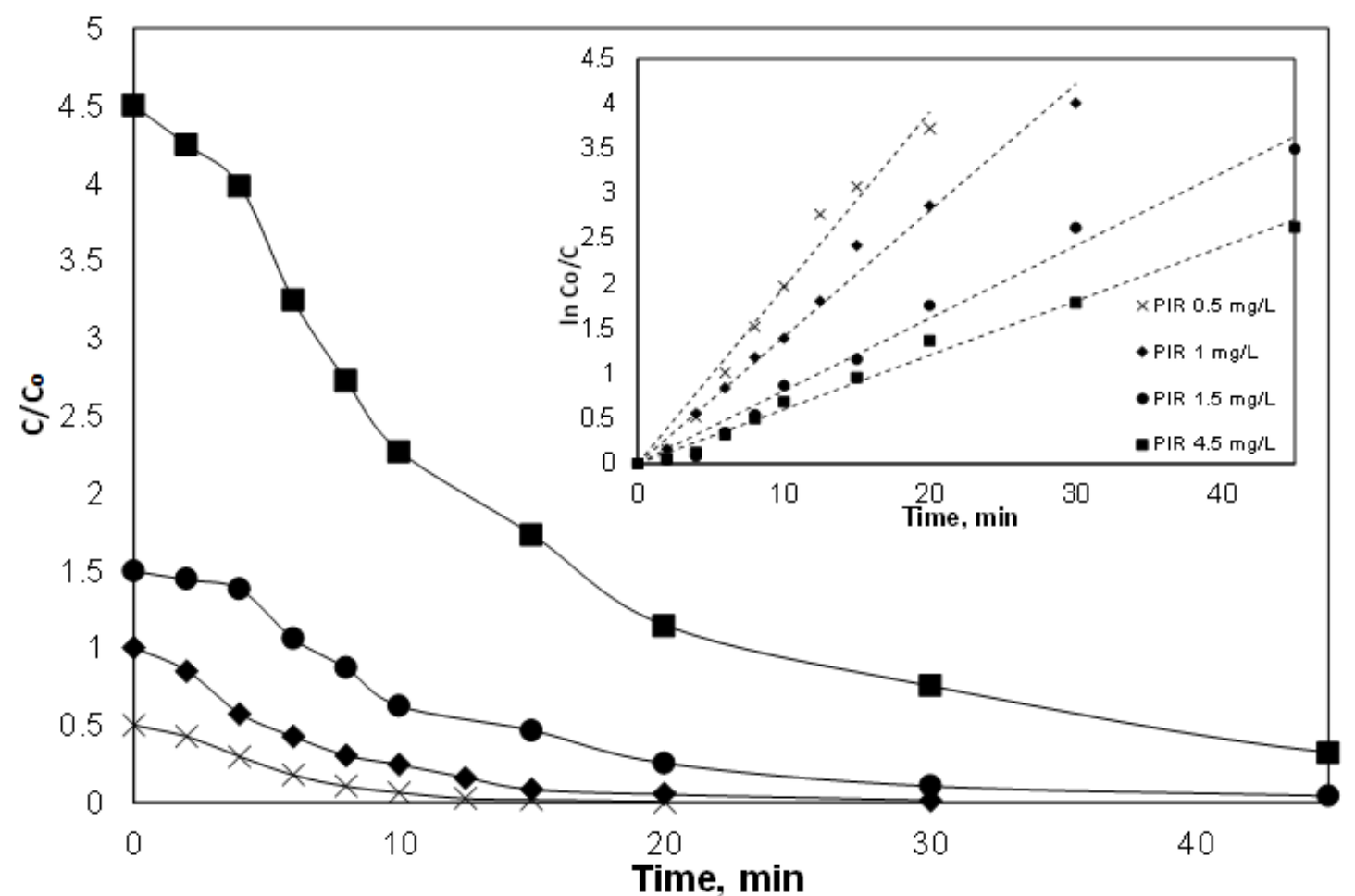

Figure 2. Effect of initial PIR concentration on its degradation at $50{ }^{\circ} \mathrm{C}$ in UPW and $100 \mathrm{mg} / \mathrm{L} \mathrm{SPS}$. Inset: Observed kinetic constants according to Equation (4).

Assuming that PIR degradation follows a pseudo-first-order kinetic expression [38], the observed (apparent) rate constant can be computed as follows:

$$
-\frac{\mathrm{dC}}{\mathrm{dt}}=\mathrm{k}_{\mathrm{obs}} \mathrm{C} \leftrightarrow \ln \frac{\mathrm{C}}{\mathrm{C}_{\mathrm{O}}}=-\mathrm{k}_{\mathrm{obs}} \mathrm{t}
$$

Using the data from Figure 2 and applying the linearized form of Equation (4), kinetic constants are shown in Table 1, while the linear plot is depicted in the inset of Figure 2. It is evident that higher concentrations of PIR result in lower kinetic constants, which implies that the reaction is not true first-order, in which case the constant should be independent of the initial concentration [39,40]. 
Table 1. Summarized data from Figures 1-10, experimental conditions and apparent kinetic constants.

\begin{tabular}{|c|c|c|c|c|c|}
\hline [PIR] (mg/L) & Irradiation & $\operatorname{Temp}\left({ }^{\circ} \mathrm{C}\right)$ & SPS (mg/L) & Water Matrix & $\mathrm{k}_{\text {obs }} \times 10^{-3}\left(\mathrm{~min}^{-1}\right)$ \\
\hline 0.5 & - & 40 & - & UPW & 4.0 \\
\hline 0.5 & - & 40 & 50 & UPW & 28.8 \\
\hline 0.5 & _- & 40 & 100 & UPW & 77.1 \\
\hline 0.5 & - & 40 & 250 & UPW & 113.4 \\
\hline 0.5 & - & 50 & 100 & UPW & 228.0 \\
\hline 1 & - & 50 & 100 & UPW & 139.0 \\
\hline 1.5 & - & 50 & 100 & UPW & 83.7 \\
\hline 4.5 & - & 50 & 100 & UPW & 60.3 \\
\hline 0.5 & - & 40 & 100 & UPW & 754.0 \\
\hline 0.5 & - & 60 & - & UPW & 5.0 \\
\hline 0.5 & - & 40 & 100 & UPW pH 3 & 25.7 \\
\hline 0.5 & - & 40 & 100 & UPW pH 5 & 75.1 \\
\hline 0.5 & - & 40 & 100 & UPW pH 8 & 37.1 \\
\hline 0.5 & - & 40 & 100 & UPW pH 9 & 9.3 \\
\hline 0.5 & Solar & 25 & - & UPW & 4.0 \\
\hline 0.5 & UV-A LED & 25 & - & UPW & 4.0 \\
\hline 0.5 & Solar & 25 & 250 & UPW & 61.5 \\
\hline 0.5 & UV-A LED & 25 & 250 & UPW & 115 \\
\hline 0.5 & - & 25 & 250 & UPW & 14.4 \\
\hline 0.5 & - & 25 & 250 & WW & 21.7 \\
\hline 0.5 & Solar & 25 & 250 & WW & 206.3 \\
\hline 0.5 & UV-A LED & 25 & 250 & WW & 74.7 \\
\hline 0.5 & - & 25 & 250 & 20 mg/L HA & 9.5 \\
\hline 0.5 & Solar & 25 & 250 & $20 \mathrm{mg} / \mathrm{L} \mathrm{HA}$ & 31.6 \\
\hline 0.5 & UV-A LED & 25 & 250 & $20 \mathrm{mg} / \mathrm{L} \mathrm{HA}$ & 17.1 \\
\hline 0.5 & Solar & 25 & 250 & $50 \mathrm{NaCl}$ & 197.0 \\
\hline 0.5 & Solar & 25 & 250 & $125 \mathrm{NaCl}$ & 175.6 \\
\hline 0.5 & Solar & 25 & 250 & $250 \mathrm{NaCl}$ & 167.1 \\
\hline 0.5 & Solar & 25 & 250 & 50 BIC & 103.1 \\
\hline 0.5 & Solar & 25 & 250 & $125 \mathrm{BIC}$ & 154.4 \\
\hline 0.5 & Solar & 25 & 250 & $250 \mathrm{BIC}$ & 141.2 \\
\hline 0.5 & Solar & 25 & 250 & $10 \mathrm{~g} / \mathrm{L} \mathrm{t}-\mathrm{butOH}$ & 4.7 \\
\hline 0.5 & Solar & 25 & 250 & $10 \mathrm{~g} / \mathrm{L} \mathrm{MeOH}$ & 6.6 \\
\hline 0.5 & - & 40 & 250 & 20 mg/L HA & 17.6 \\
\hline 0.5 & Solar & 40 & 250 & 20 mg/L HA & 155.7 \\
\hline 0.5 & - & 40 & 250 & WW & 24.0 \\
\hline 0.5 & UV-A LED & 40 & 250 & WW & 237.0 \\
\hline
\end{tabular}

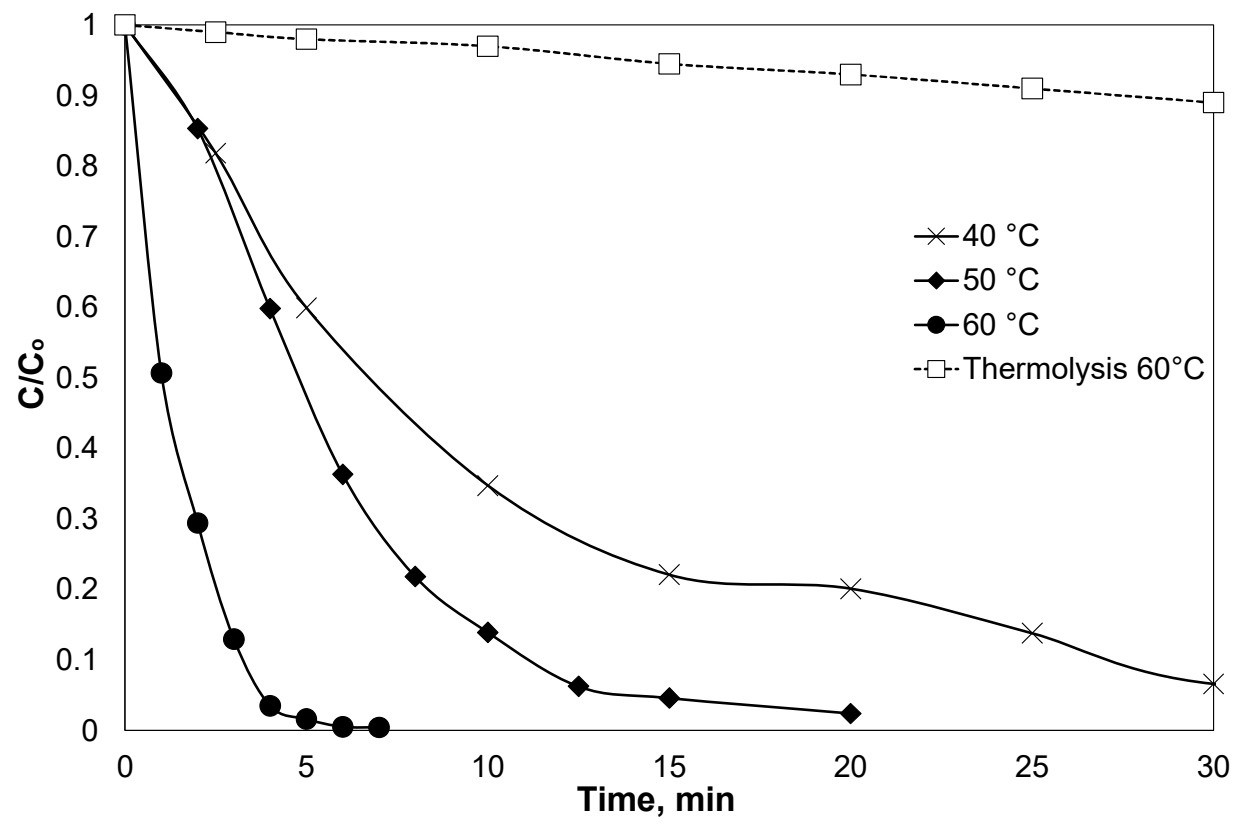

Figure 3. Effect of activation temperature on $0.5 \mathrm{mg} / \mathrm{L} \mathrm{PIR} \mathrm{degradation} \mathrm{in} \mathrm{UPW} \mathrm{and} 100 \mathrm{mg} / \mathrm{L}$ SPS. 


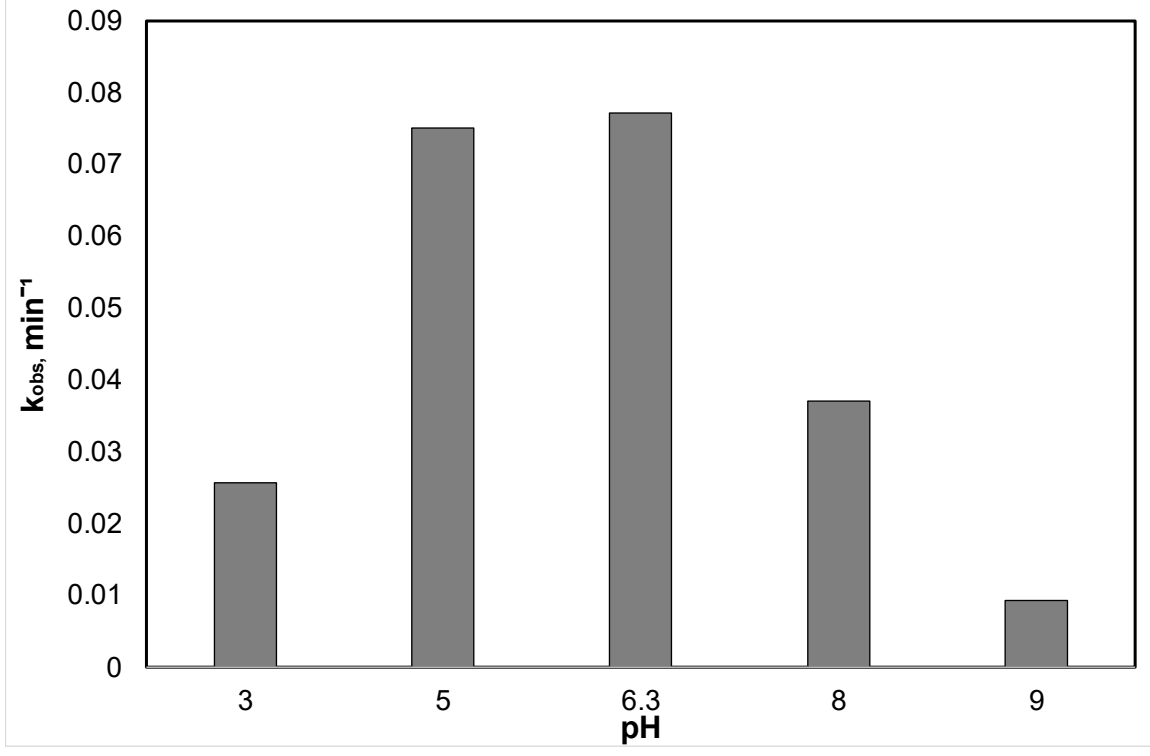

Figure 4. Effect of $\mathrm{pH}$ on $0.5 \mathrm{mg} / \mathrm{L}$ PIR degradation at $40^{\circ} \mathrm{C}$ in UPW and $100 \mathrm{mg} / \mathrm{L} \mathrm{SPS}$.
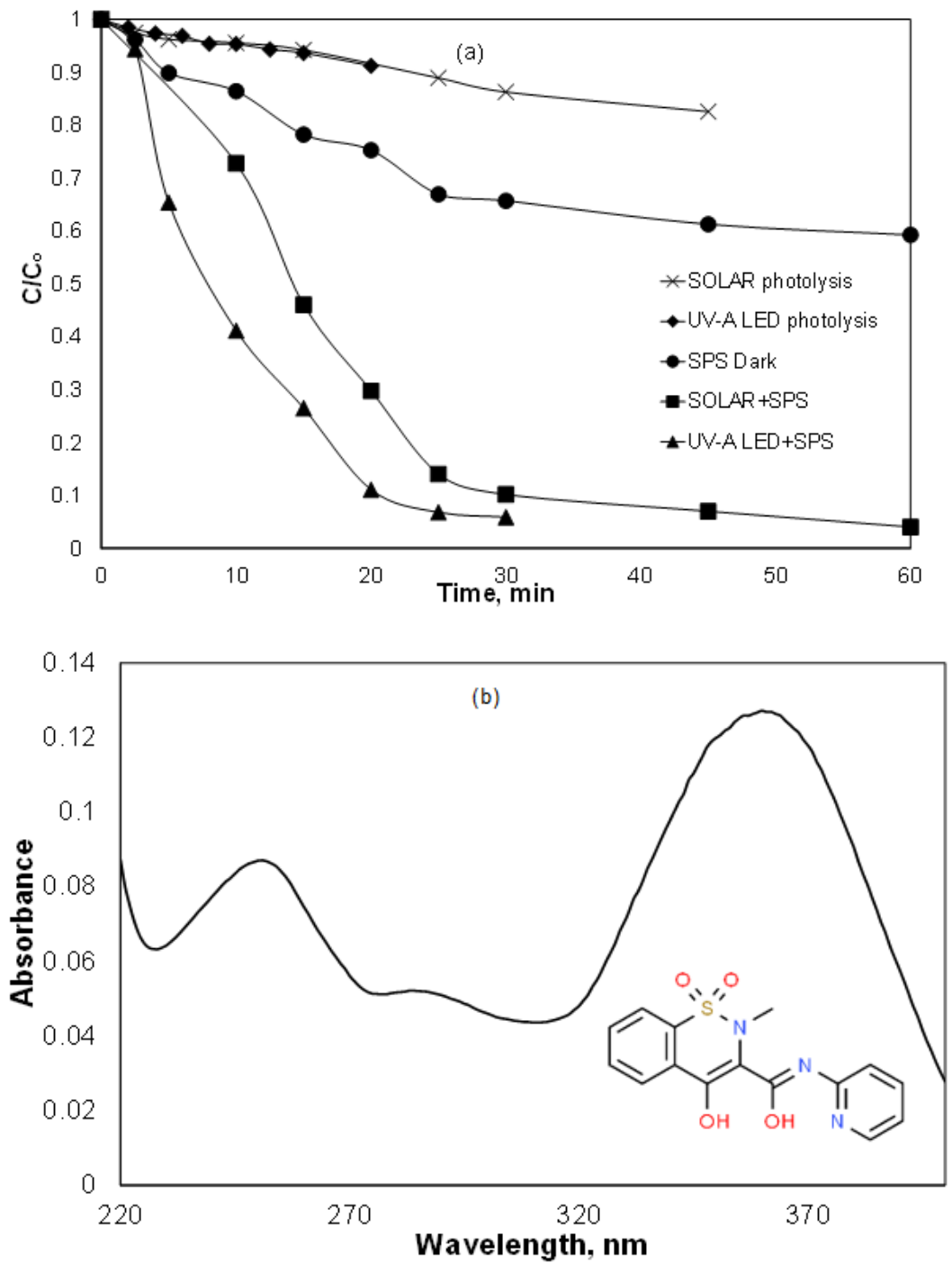

Figure 5. (a) Effect of radiation source on $0.5 \mathrm{mg} / \mathrm{L} \mathrm{PIR} \mathrm{degradation} \mathrm{at} 25^{\circ} \mathrm{C}$ in UPW and $250 \mathrm{mg} / \mathrm{L} \mathrm{SPS}$. Blank and dark experiments are also shown. (b) Absorbance spectrum of piroxicam. 


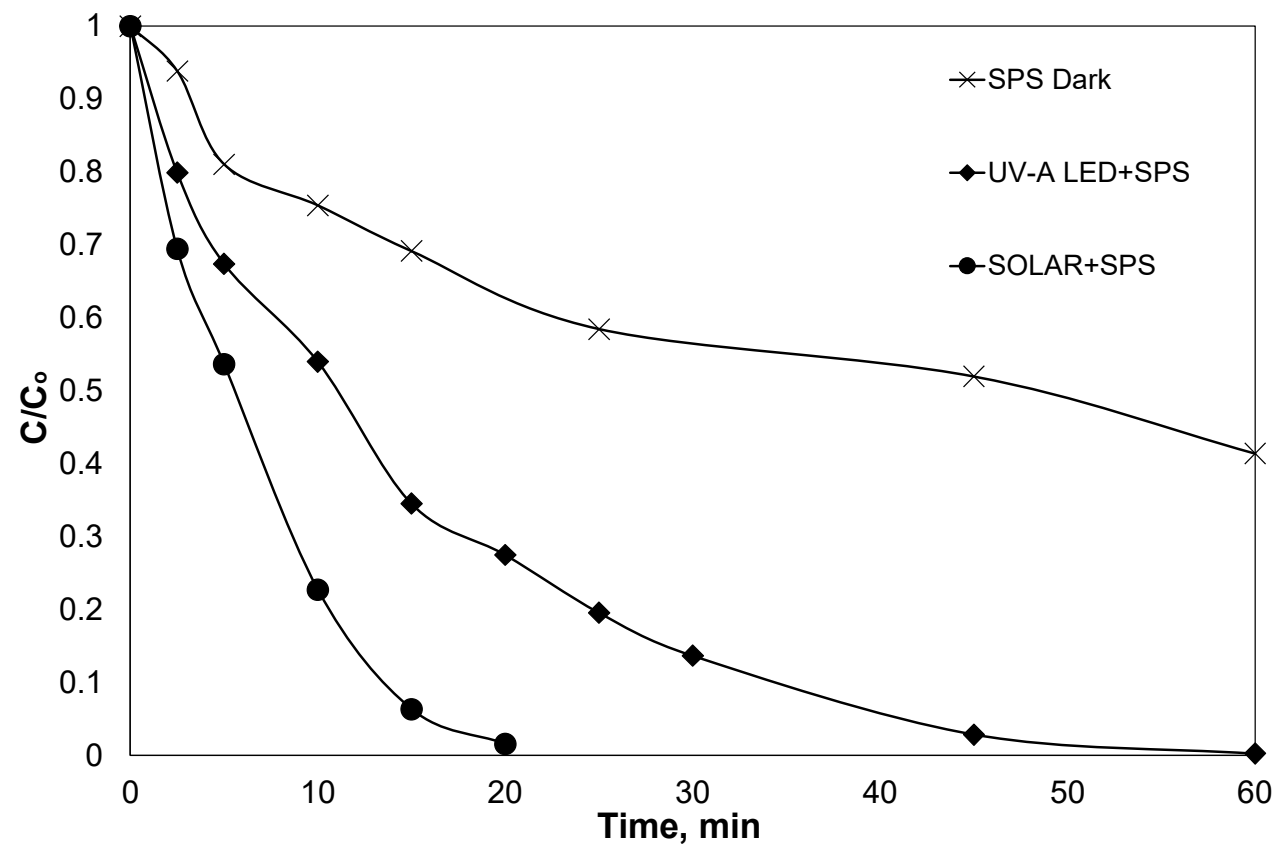

Figure 6. Effect of radiation source on $0.5 \mathrm{mg} / \mathrm{L}$ PIR degradation at $25{ }^{\circ} \mathrm{C}$ in secondary treatment effluent (WW) and $250 \mathrm{mg} / \mathrm{L} \mathrm{SPS.}$

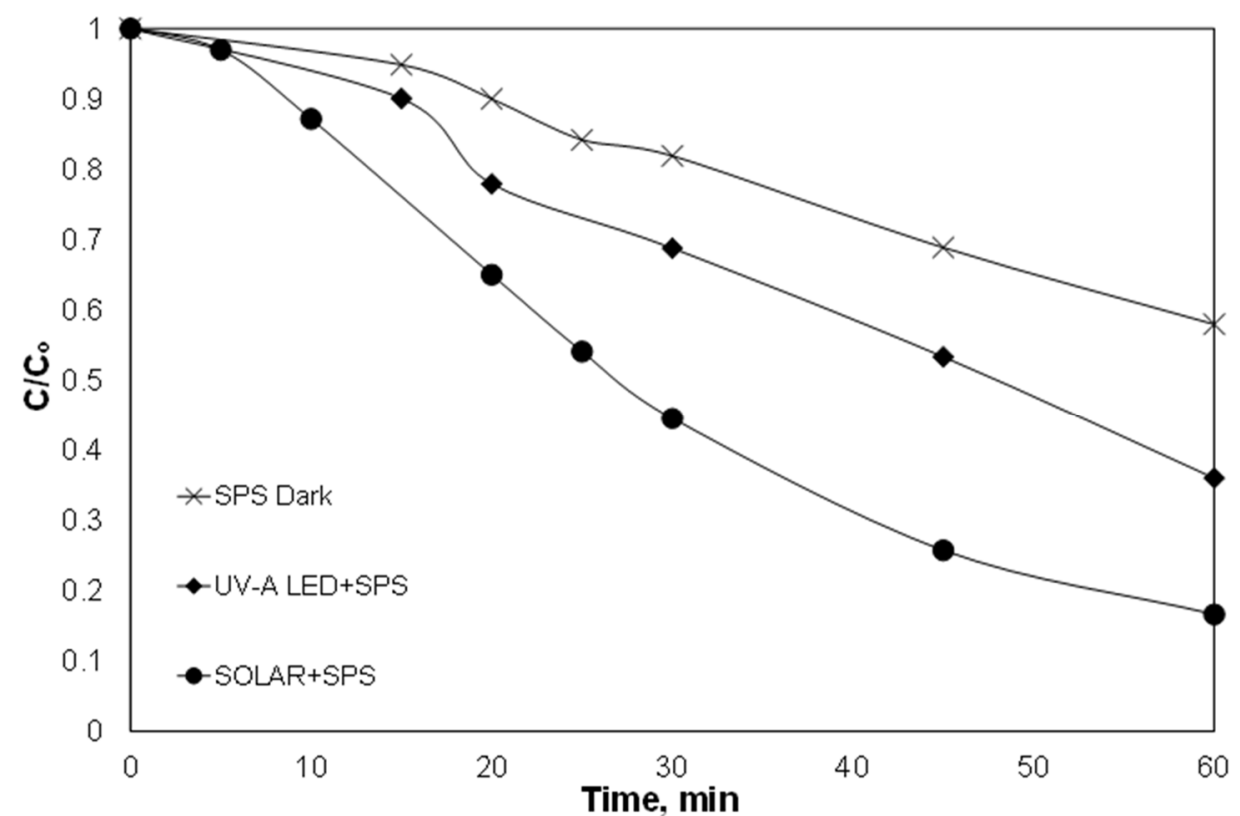

Figure 7. Effect of radiation source on $0.5 \mathrm{mg} / \mathrm{L}$ PIR degradation at $25^{\circ} \mathrm{C}$ in UPW spiked with $20 \mathrm{mg} / \mathrm{L}$ $\mathrm{HA}$ and $250 \mathrm{mg} / \mathrm{L}$ SPS. 


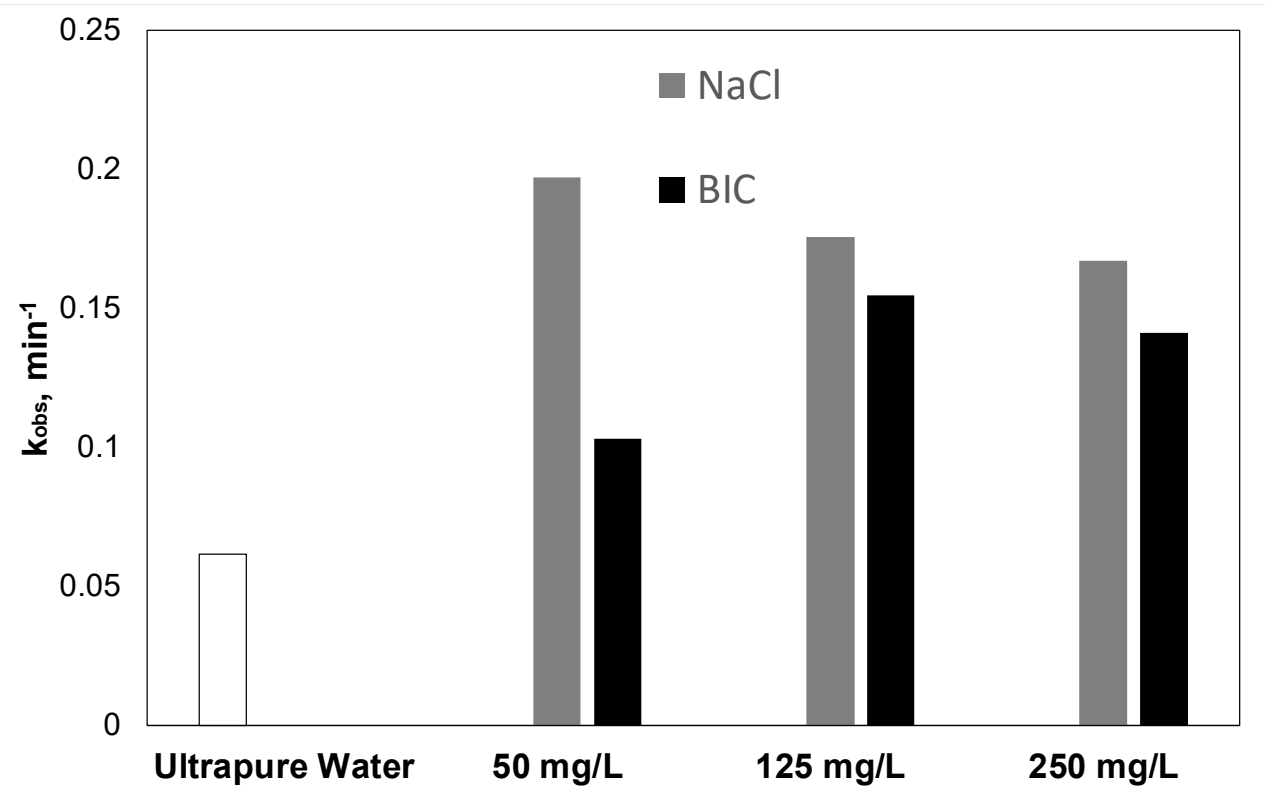

Figure 8. Effect of inorganic ions on $0.5 \mathrm{mg} / \mathrm{L}$ PIR degradation with simulated solar radiation at $25^{\circ} \mathrm{C}$ in UPW and $250 \mathrm{mg} / \mathrm{L} \mathrm{SPS}$. BIC: Bicarbonate.

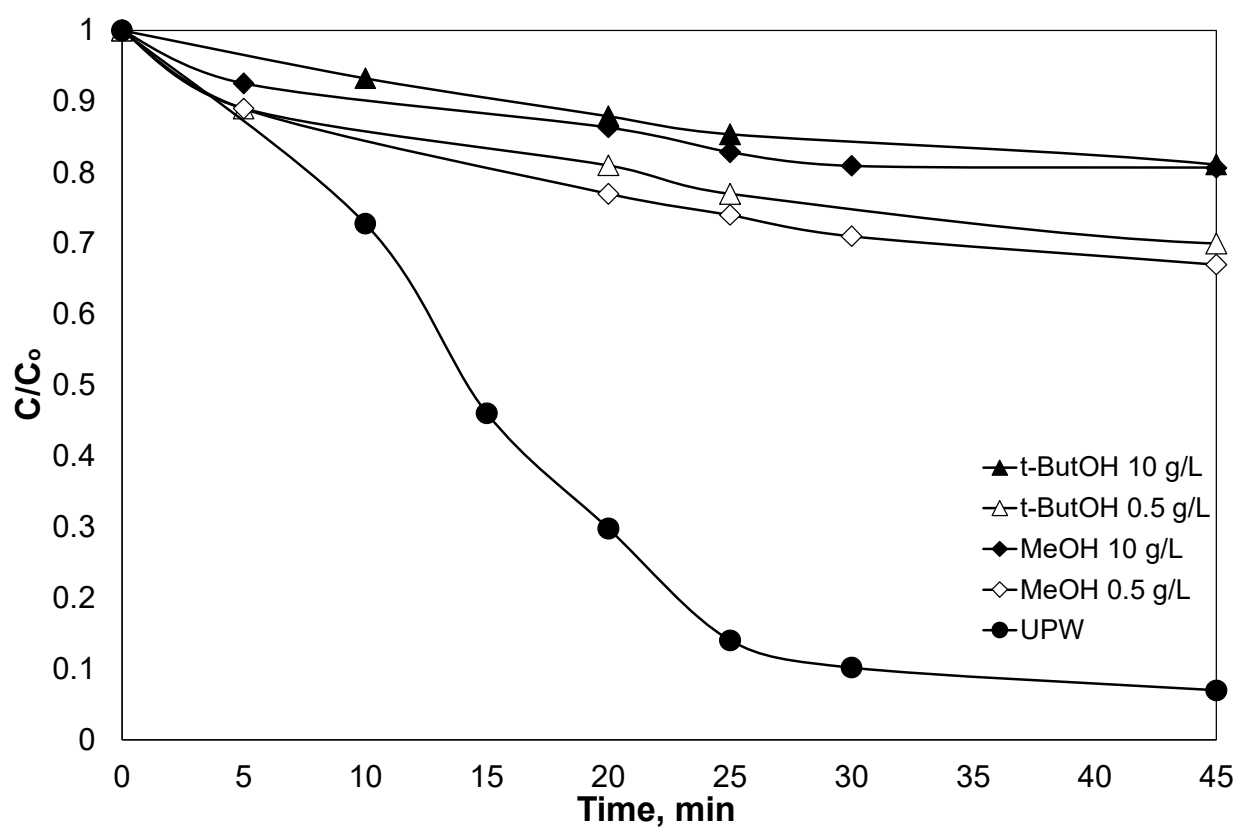

Figure 9. Effect of radical scavengers on $0.5 \mathrm{mg} / \mathrm{L}$ PIR degradation with solar radiation at $25^{\circ} \mathrm{C}$ in UPW and $250 \mathrm{mg} / \mathrm{L}$ SPS. 

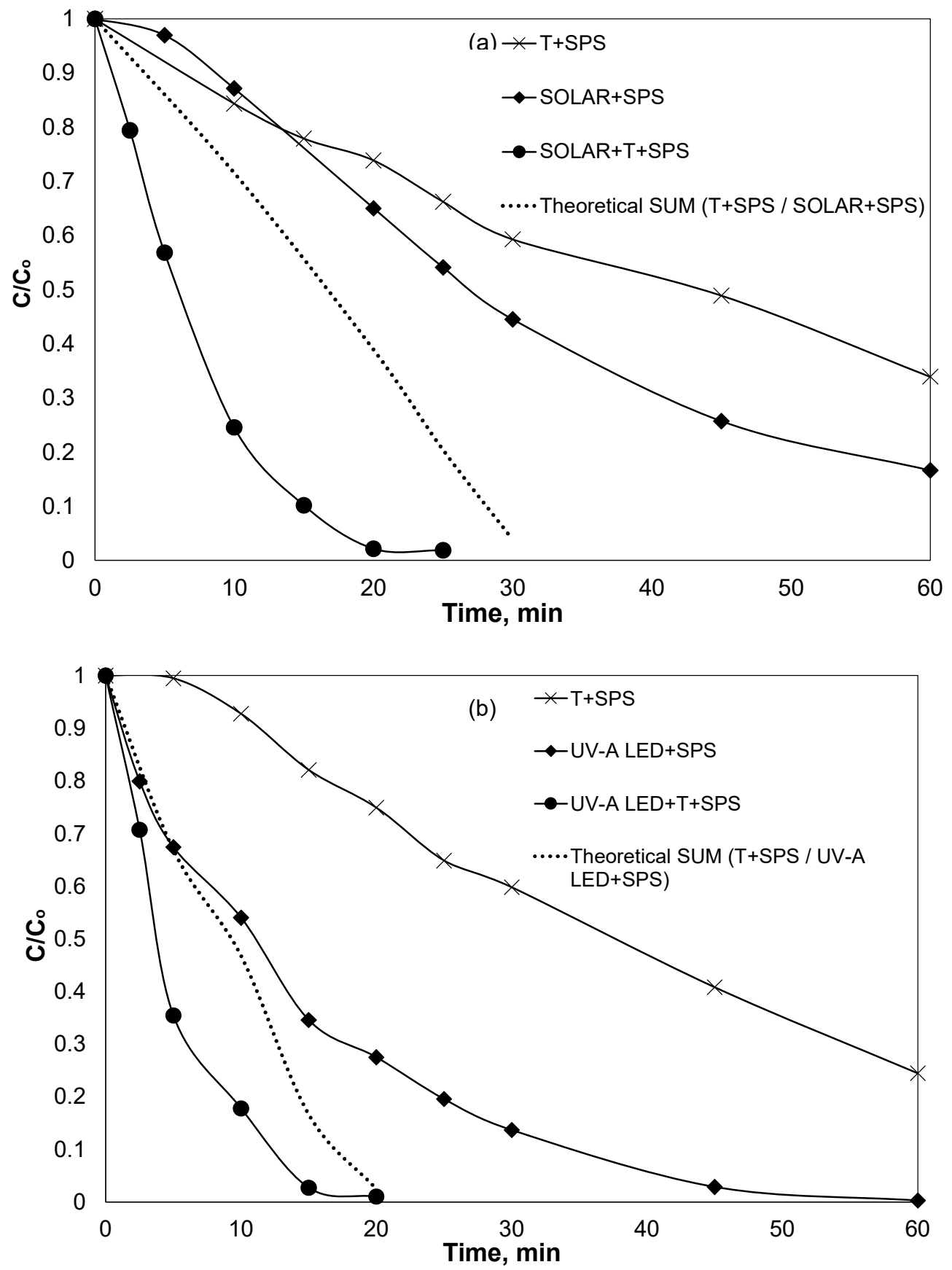

Figure 10. Effect of coupling thermal and light activation methods of SPS $(250 \mathrm{mg} / \mathrm{L})$ for the degradation of $0.5 \mathrm{mg} / \mathrm{L}$ PIR. (a) Experiments with simulated solar light in UPW spiked with $20 \mathrm{mg} / \mathrm{L} \mathrm{HA}$. (b) Experiments with UV-A LED in WW. Dotted line: Theoretical sum of light and heat activation.

\subsection{Effect of Activation Temperature}

PIR removal was studied in the range $40-60{ }^{\circ} \mathrm{C}$ and the results are shown in Figure 3. Evidently, degradation is favored at higher activation temperatures, leading to complete removal after only $5 \mathrm{~min}$ at $60{ }^{\circ} \mathrm{C}$. The observed kinetic constants are computed equal to $0.077,0.223$ and $0.755 \mathrm{~min}^{-1}$ at 40,50 and $60^{\circ} \mathrm{C}$, respectively.

Thermal or light activation of SPS acts along the same pathway. Either means of activation breaks down the persulfate anion into sulfate radicals by consuming energy as shown in Equation $(5)[22,26,27]$.

$$
\mathrm{S}_{2} \mathrm{O}_{8}^{2-}+\text { energy } \rightarrow 2 \mathrm{SO}_{4}^{-\bullet}
$$


Absorbing thermal energy, persulfate salts produce two sulfate radicals with an activation energy of 119-129, 134-139 and 100-116 kJ/mol at inherent, alkaline and acidic conditions, respectively [22]. From previous studies [41], it was found that the reaction temperature plays a key role because higher temperatures result in higher rates of pollutant removal and higher solubility of the substance.

However, it is essential to reach the right balance between the reaction temperature and the degree of pollutant removal since higher temperatures are unavoidably more energy-consuming.

\subsection{Effect of $p H$}

Since environmental samples and pharmaceutical wastewaters may have different $\mathrm{pH}$ values, another set of experiments were conducted to determine the effect of $\mathrm{pH}$ on the efficiency of the process. From Figure 4, the beneficial effect of working at inherent $\mathrm{pH}$ conditions is obvious since the observed kinetic constants decrease substantially as $\mathrm{pH}$ shifts from its inherent value of 6.3 to acidic or alkaline conditions. At alkaline conditions, sulfate radicals are transformed rapidly to hydroxyl radicals which have greater redox potential but shorter lifespan in comparison with sulfate radicals. The lifetime of hydroxyl and sulfate radicals has been estimated in the order of $10^{-3}$ and $40-50 \mu \mathrm{s}$, respectively [26,42].

$$
\begin{gathered}
\mathrm{SO}_{4}^{-\bullet}+\mathrm{H}_{2} \mathrm{O} \rightarrow \mathrm{SO}_{4}^{2-}+\mathrm{OH}^{\bullet}+\mathrm{H}^{+} \\
\mathrm{SO}_{4}^{-\bullet}+\mathrm{OH}^{-} \rightarrow \mathrm{SO}_{4}^{2-}+\mathrm{OH}^{\bullet}
\end{gathered}
$$

On the other hand, and although sulfate radicals are the dominant species at acidic conditions, they are partly wasted to the production of non-reactive $\mathrm{HSO}_{4}^{-}$, thus leading to lower degradation rates.

$$
\mathrm{SO}_{4}^{-\bullet}+\mathrm{H}^{+} \rightarrow \mathrm{HSO}_{4}^{-}
$$

In contrast, under inherent conditions both sulfate and hydroxyl radicals are active leading to a more efficient degradation process for the pollutant in question. At the same time, it is well known that the redox potential of active species is a function of $\mathrm{pH}$. Therefore, in homogeneous systems, the observed yield depends on the selectivity of the produced reactive species towards the target compounds, as well as on the redox potential in the current conditions [43].

\subsection{Effect of Light Activation}

Despite the encouraging results presented above, a significant disadvantage of SPS thermal activation is the increased cost. In this light, the use of artificial or natural radiation to activate SPS could be an attractive option. Figure 5 shows PIR degradation using the two different sources of radiation under ambient conditions $\left(25^{\circ} \mathrm{C}\right)$. Either seems capable of effectively activating SPS and, consequently degrading PIR; its $30-\mathrm{min}$ removal is $94.1 \%$ and $89.8 \%$ with the UV-A LED and solar light, respectively.

Blank experiments were also performed showing that photolysis alone (i.e., without SPS) does not contribute significantly to degradation and is independent of the light source; this is rather expected since no reactive radicals are formed, while both radiation sources have similar photon fluxes [44]. A dark experiment was also performed in the presence of SPS leading to partial PIR degradation (i.e., $34.2 \%$ after $60 \mathrm{~min})$.

The advantageous usage of ultraviolet radiation is known from previous studies [45,46]. The absorbance spectrum of PIR is depicted in Figure $5 b$ and shows a maximum in the UV-A region. Therefore, piroxicam can be decomposed in two distinct ways: (i) direct (UV-A) photo-degradation, where the pollutant directly absorbs photons and (ii) through reactive radicals derived from the ultraviolet activation of SPS.

Therefore, the decay of piroxicam can be described as follows:

$$
\frac{\mathrm{d}[\mathrm{PIR}]}{\mathrm{dt}}=-\left(\mathrm{k}_{\text {photolysis }}[\mathrm{PIR}]+\mathrm{k}_{\mathrm{HO}}, \mathrm{PIR}\left[\mathrm{HO} \cdot[\mathrm{PIR}]+\mathrm{k}_{\mathrm{SO}_{4}^{-\bullet}, \mathrm{PIR}}\left[\mathrm{SO}_{4}^{-\bullet}\right][\mathrm{PIR}]\right)\right.
$$


or in a simplified form

$$
\frac{\mathrm{d}[\mathrm{PIR}]}{\mathrm{dt}}=-\mathrm{k}_{\text {light-activated SPS }}[\mathrm{PIR}]
$$

where

$$
\mathrm{k}_{\text {light }- \text { activated SPS }}=\mathrm{k}_{\text {photolysis }}+\mathrm{k}_{\mathrm{HO}}, \mathrm{PIR}_{\mathrm{PIR}}\left[\mathrm{HO}^{\bullet}\right]+\mathrm{k}_{\mathrm{SO}_{4}^{-}, \mathrm{PIR}}\left[\mathrm{SO}_{4}^{-\bullet}\right]
$$

These results are in line with a recent study of our group that demonstrated that the UV-A spectrum of solar radiation could activate SPS [31]. Recently, Wang et al. [47] demonstrated that visible light $(420 \mathrm{~nm})$ could activate persulfate and this was employed to inactivate E. coli cells.

\subsection{Effect of Water Matrix}

To gain a better insight of process efficiency, more complex matrices must be used to simulate environmental samples and provide a more realistic approach. In this regard, experiments in secondary treated effluent (WW) containing various inorganic and organic components were performed. As can be seen from Figures 5 and 6, the solar light activated persulfate process performs better in WW than in UPW leading to complete PIR removal in $20 \mathrm{~min}$. This implies possible interactions amongst the water constituents (organic and/or inorganic), the oxidant and the pollutant that seem to promote PIR degradation. Although such interactions are usually complex and difficult to differentiate, an attempt was made to shed light on the effect of organic and inorganic species.

Further experiments were performed in UPW spiked with $20 \mathrm{mg} / \mathrm{L}$ humic acid (this resulted in $8.4 \mathrm{mg} / \mathrm{L}$ of total organic carbon, comparable to the organic content inherently present in WW). Humic acid simulates the resistant natural organic matter that typically exists in surface and ground waters, as well as in secondary effluents $[45,48]$. As can be seen in Figure 7 , the presence of humic acid impedes PIR degradation relative to the experiments in UPW or WW and this seems to be the case for both radiation sources. For instance, the extent of PIR degradation under simulated solar irradiation was 83\% after $60 \mathrm{~min}$ in UPW spiked with HA, 95\% after $60 \mathrm{~min}$ in UPW and 100\% after $20 \mathrm{~min}$ in WW. The detrimental effect of humic acid is due to its action as a scavenger of reactive radicals and competition with persulfate for the available photons [49]. Nevertheless, the better performance of solar radiation observed in the experiments of the secondary effluent compared with the experiments with humic acid deserves further investigation.

From the results shown in Figures 5-7, the role of inorganic matrix species seems to be important and this is more pronounced for the experiments with solar light persulfate activation. In this respect, UPW was added chloride or bicarbonate in the range $50-250 \mathrm{mg} / \mathrm{L}$ and the results, in terms of the observed kinetic constants, are depicted in Figure 8 and Table 1. The addition of either anion enhances PIR degradation for the whole range of concentrations tested.

Regarding the effect of chloride, the kinetic constant slightly decreases from $0.197 \mathrm{~min}^{-1}$ to $0.167 \mathrm{~min}^{-1}$ when its concentration increases from 50 to $250 \mathrm{mg} / \mathrm{L}$, yet this is about three times greater than that without salt. The addition of chloride may have either beneficial or antagonistic effects and has caused controversy among the scientific community [50,51]. Chloride ions interact with sulfate and hydroxyl radicals leading to the formation of chloride radicals as follows:

$$
\begin{aligned}
\mathrm{SO}_{4}^{-\bullet}+\mathrm{Cl}^{-} & \rightarrow \mathrm{Cl}^{\bullet}+\mathrm{SO}_{4}^{2-} \\
\mathrm{HO}^{\bullet}+\mathrm{Cl}^{-} & \rightarrow \mathrm{HOCl}^{\bullet} \\
\mathrm{HOCl}^{\bullet}+\mathrm{H}^{+} & \rightarrow \mathrm{Cl}^{\bullet}+\mathrm{H}_{2} \mathrm{O}
\end{aligned}
$$

Chloride radicals may contribute, besides sulfate and hydroxyl radicals, to the degradation of the pollutant; nonetheless, high concentrations of chloride ion may behave as radical scavengers leading to a detrimental effect [43]. Indeed, the presence of $200 \mathrm{mg} / \mathrm{L}$ chloride increased the apparent kinetic constant of piroxicam electrochemical oxidation by almost ten times [52]. A similar behavior was observed by Outsiou et al. [53], where the addition of more than $50 \mathrm{mg} / \mathrm{L}$ chloride increased the 
removal of bisphenol A using SPS activated by a bimetallic carbon xerogel catalyst. On the contrary, the presence of chloride did not have any particular effect on the destruction of piroxicam using iron-activated persulfate [30]. However, the effect of chloride needs further investigation as several studies have linked its presence to the formation of organochlorine compounds that are potentially carcinogenic [52].

Bicarbonate, a major compound in terms of the concentration of ions present in environmental samples, is usually responsible for reduced treatment efficiency due to its scavenging reaction with active oxidizing agents [40]. However, recent research suggests that the effect of bicarbonate on different advanced oxidation processes is not necessarily negative but depends on the experimental conditions [32]. The presence of bicarbonate, depending on the pollutant under consideration, may lead to an increase in degradation efficiency [54].

As seen in Figure 8, the presence of bicarbonate also enhances piroxicam degradation and this may be associated with the formation of carbonate radicals. Although the latter are less reactive than hydroxyl and sulfate radicals, they are selective electrophilic reagents that may exhibit different reactivities, depending on the characteristics of organic pollutants. It is worth noting that the addition of bicarbonate increased solution $\mathrm{pH}$ to 8.1. However, the increase in piroxicam removal cannot be explained by the $\mathrm{pH}$ change. As mentioned in Section 3.4, removal was favored at $\mathrm{pH}$ values between 5 and 6.3. For a specific $\mathrm{pH}$ value, the relative distribution of the three radicals according to Equations (15) and (16) is likely to be affected by the initial bicarbonate concentration and this eventually dictates the oxidizing capacity and behavior of the system $[51,55]$.

$$
\begin{gathered}
\mathrm{HCO}_{3}^{-}+\mathrm{SO}_{4}^{-} \rightarrow \mathrm{CO}_{3}^{-}+\mathrm{SO}_{4}^{2-}+\mathrm{H}^{+} \\
\mathrm{HCO}_{3}^{-}+\mathrm{HO} \rightarrow \mathrm{CO}_{3}^{-}+\mathrm{H}_{2} \mathrm{O}
\end{gathered}
$$

Recently, Frontistis [30] investigated the degradation of $0.5 \mathrm{mg} / \mathrm{L}$ piroxicam using $2 \mathrm{mg} / \mathrm{L} \mathrm{Fe}^{2+}$ and $20 \mathrm{mg} / \mathrm{L}$ SPS at inherent $\mathrm{pH}$. The researcher observed only a slight decrease in the presence of $100-250 \mathrm{mg} / \mathrm{L}$ bicarbonate. In another study of our group that examined the electrochemical oxidation of piroxicam over boron doped diamond anode [52], the presence of $100 \mathrm{mg} / \mathrm{L}$ bicarbonate increased the observed kinetic constant almost 4.5 times, i.e., from $0.138 \mathrm{~min}^{-1}$ to $0.624 \mathrm{~min}^{-1}$ in comparison with ultrapure water.

\subsection{Effect of Radical Scavengers}

To shed light on the mechanism of piroxicam oxidation, experiments were conducted using an excess of tert-butanol or methanol since these alcohols are often used as radical scavengers. More specifically, tert-butanol has a greater affinity to hydroxyl radicals $\left.\mathrm{k}_{(\mathrm{t}-\mathrm{ButOH}, \mathrm{HO}}{ }^{\bullet}\right)=5.2 \times 10^{8} \mathrm{M}^{-1} \cdot \mathrm{s}^{-1}$ than sulfate radicals $\mathrm{k}_{\left(\mathrm{t}-\mathrm{ButOH}, \mathrm{SO}_{4}^{-\bullet}\right)}{ }^{-}=10^{6} \mathrm{M}^{-1} \cdot \mathrm{s}^{-1}$ while methanol can scavenge both radicals $\left.\mathrm{k}_{(\mathrm{MeOH}, \mathrm{HO}}\right)^{*}$ $\left.\left.=8 \times 10^{8} \mathrm{M}^{-1} \cdot \mathrm{s}^{-1}, \mathrm{k}_{\left(\mathrm{MeOH}, \mathrm{SO}^{-}\right.}{ }^{-\bullet}\right)=10^{7} \mathrm{M}^{-1} \cdot \mathrm{s}^{-1}\right)[56,57]$.

As seen in Figure 9, the use of either alcohol at 0.5 or $10 \mathrm{~g} / \mathrm{L}$ practically quenches degradation; this indirectly implies that, although sulfate and hydroxyl radicals are both responsible for piroxicam decomposition, hydroxyl radicals are most likely the predominant species in the conditions studied [58].

\subsection{Coupling Thermal and Light Activation Methods}

In a final series of experiments, the simultaneous application of thermal and light activation of SPS was evaluated. Thermal activation was implemented at $40{ }^{\circ} \mathrm{C}$ to minimize energy consumption and it was coupled with either UV-A LED or simulated solar light. The combined thermal and solar light activation process (SPS + SOLAR + T) was tested for PIR degradation in UPW spiked with $20 \mathrm{mg} / \mathrm{L}$ HA (Figure 10a), while the combined thermal and UV-A LED process (SPS + UV-A LED + T) for PIR degradation in WW (Figure 10b). Figure 10 also shows the respective individual runs, i.e., only thermal activation at $40{ }^{\circ} \mathrm{C}$ or light activation at $25^{\circ} \mathrm{C}$. The theoretical sum of the two processes is illustrated by a dotted line. 
In either case, complete PIR degradation was achieved in less than 15-20 min when thermal and light activation methods were applied simultaneously. PIR removal was considerably faster than the respective methods applied individually, as well as their theoretical sum represented by the dotted line. Based on Equations (2) and (3) and the values shown in Table 1, the degrees of synergy and enhancement are computed equal to $68.4 \%$ and $88.7 \%$, respectively, for the experiments of Figure 10a, and $58.4 \%$ and $89.9 \%$, respectively, for the experiments of Figure $10 \mathrm{~b}$. These results clearly demonstrate that the combined application of the two activation methods has a beneficial synergistic rather than a mere cumulative (additive) effect.

\section{Conclusions}

The scope of this study was to investigate the degradation of the NSAID piroxicam using various persulfate-based oxidation processes, while considering the effects of different operating parameters. The main conclusions derived from this work are as follows:

- Both thermal and light activated sodium persulfate can achieve high levels of piroxicam degradation.

- The process is favored at near neutral $\mathrm{pH}$. Although both sulfate and hydroxyl radicals seem to contribute to the decomposition of piroxicam, hydroxyl radicals were the dominant species.

- Secondary effluent has an unexpectedly beneficial effect on the process, in comparison with experiments in ultrapure water.

- Inorganic ions like chloride and bicarbonate enhance process efficiency.

- Coupling thermal and light activation methods results in synergistic enhancement with obvious implications for reducing the cost of treatment and minimizing environmental footprint.

Author Contributions: Investigation, A.S. and Z.F.; Methodology, Z.F. and D.M.; Resources, Z.F. and D.M.; Supervision, Z.F. and D.M., writing-Review and editing A.S., Z.F. and D.M. All authors have read and agreed to the published version of the manuscript.

Funding: Zacharias Frontistis acknowledges that this work is part of the project "2De4P: Development and Demonstration of a Photocatalytic Process for removing Pathogens and Pharmaceuticals from wastewaters" which is implemented under the Action "H.F.R.I.-1st Call for Research Projects to Support Post-Doctoral Researchers," funded by H.F.R.I. Hellenic Foundation for Research and Innovation and General Secretariat for Research and Technology (GSRT).

Conflicts of Interest: The authors declare no conflict of interest.

\section{References}

1. Luo, Y.; Guo, W.; Ngo, H.H.; Nghiem, L.D.; Hai, F.I.; Zhang, J.; Liang, S.; Wang, X.C. A review on the occurrence of micropollutants in the aquatic environment and their fate and removal during wastewater treatment. Sci. Total Environ. 2014, 473-474, 619-641. [CrossRef] [PubMed]

2. Tijani, J.O.; Fatoba, O.O.; Petrik, L.F. A review of pharmaceuticals and endocrine-disrupting compounds: Sources, effects, removal, and detections. Water. Air Soil Pollut. 2013, 224, 1-29. [CrossRef]

3. Dalrymple, O.K.; Yeh, D.H.; Trotz, M.A. Removing pharmaceuticals and endocrine-disrupting compounds from wastewater by photocatalysis. J. Chem. Technol. Biotechnol. 2007, 82, 121-134. [CrossRef]

4. Causanilles, A.; Ruepert, C.; Ibáñez, M.; Emke, E.; Hernández, F.; de Voogt, P. Occurrence and fate of illicit drugs and pharmaceuticals in wastewater from two wastewater treatment plants in Costa Rica. Sci. Total Environ. 2017, 599-600, 98-107. [CrossRef]

5. Lin, H.; Li, H.; Chen, L.; Li, L.; Yin, L.; Lee, H.; Yang, Z. Mass loading and emission of thirty-seven pharmaceuticals in a typical municipal wastewater treatment plant in Hunan Province, Southern China. Ecotoxicol. Environ. Saf. 2018, 147, 530-536. [CrossRef]

6. Nikolaou, A.; Meric, S.; Fatta, D. Occurrence patterns of pharmaceuticals in water and wastewater environments. Proc. Anal. Bioanal. Chem. 2007, 387, 1225-1234. [CrossRef]

7. Kay, P.; Blackwell, P.A.; Boxall, A.B.A. A lysimeter experiment to investigate the leaching of veterinary antibiotics through a clay soil and comparison with field data. Environ. Pollut. 2005, 134, 333-341. [CrossRef] 
8. Johnson, A.C.; Williams, R.J.; Matthiessen, P. The potential steroid hormone contribution of farm animals to freshwaters, the United Kingdom as a case study. Sci. Total Environ. 2006, 362, 166-178. [CrossRef]

9. Matamoros, V.; Bayona, J.M. Elimination of Pharmaceuticals and Personal Care Products in Subsurface Flow Constructed Wetlands. Environ. Sci. Technol. 2006, 40, 5811-5816. [CrossRef]

10. Li, H.; Dong, Z.; Weng, Q.; Chang, C.-C.; Liu, B. Emerging Pollutants-Part I: Occurrence, Fate and Transport. Water Environ. Res. 2015, 87, 1849-1872. [CrossRef]

11. Zhang, D.; Gersberg, R.M.; Ng, W.J.; Tan, S.K. Removal of pharmaceuticals and personal care products in aquatic plant-based systems: A review. Environ. Pollut. 2014, 184, 620-639. [CrossRef] [PubMed]

12. Ahmed, M.B.; Zhou, J.L.; Ngo, H.H.; Guo, W. Adsorptive removal of antibiotics from water and wastewater: Progress and challenges. Sci. Total Environ. 2015, 532, 112-126. [CrossRef] [PubMed]

13. Klamerth, N.; Malato, S.; Agüera, A.; Fernández-Alba, A. Photo-Fenton and modified photo-Fenton at neutral $\mathrm{pH}$ for the treatment of emerging contaminants in wastewater treatment plant effluents: A comparison. Water Res. 2013, 47, 833-840. [CrossRef] [PubMed]

14. Klavarioti, M.; Mantzavinos, D.; Kassinos, D. Removal of residual pharmaceuticals from aqueous systems by advanced oxidation processes. Environ. Int. 2009, 35, 402-417. [CrossRef] [PubMed]

15. Kanakaraju, D.; Glass, B.D.; Oelgemöller, M. Advanced oxidation process-mediated removal of pharmaceuticals from water: A review. J. Environ. Manag. 2018, 219, 189-207. [CrossRef] [PubMed]

16. Brodin, T.; Fick, J.; Jonsson, M.; Klaminder, J. Dilute concentrations of a psychiatric drug alter behavior of fish from natural populations. Science (80) 2013, 339, 814-815. [CrossRef]

17. Brodin, T.; Piovano, S.; Fick, J.; Klaminder, J.; Heynen, M.; Jonsson, M. Ecological effects of pharmaceuticals in aquatic systems-Impacts through behavioural alterations. Philos. Trans. R. Soc. B Biol. Sci. 2014, 369. [CrossRef]

18. Ziylan, A.; Ince, N.H. The occurrence and fate of anti-inflammatory and analgesic pharmaceuticals in sewage and fresh water: Treatability by conventional and non-conventional processes. J. Hazard. Mater. 2011, 187, 24-36. [CrossRef]

19. Lolić, A.; Paíga, P.; Santos, L.H.M.L.M.; Ramos, S.; Correia, M.; Delerue-Matos, C. Assessment of non-steroidal anti-inflammatory and analgesic pharmaceuticals in seawaters of North of Portugal: Occurrence and environmental risk. Sci. Total Environ. 2015, 508, 240-250. [CrossRef]

20. Mainero Rocca, L.; Gentili, A.; Caretti, F.; Curini, R.; Pérez-Fernández, V. Occurrence of non-steroidal anti-inflammatory drugs in surface waters of Central Italy by liquid chromatography-tandem mass spectrometry. Int. J. Environ. Anal. Chem. 2015, 95, 685-697. [CrossRef]

21. Ahmed, M.B.; Zhou, J.L.; Ngo, H.H.; Guo, W.; Thomaidis, N.S.; Xu, J. Progress in the biological and chemical treatment technologies for emerging contaminant removal from wastewater: A critical review. J. Hazard. Mater. 2017, 323, 274-298. [CrossRef] [PubMed]

22. Matzek, L.W.; Carter, K.E. Activated persulfate for organic chemical degradation: A review. Chemosphere 2016, 151, 178-188. [CrossRef] [PubMed]

23. Frontistis, Z.; Mestres, E.M.; Konstantinou, I.; Mantzavinos, D. Removal of cibacron black commercial dye with heat- or iron-activated persulfate: Statistical evaluation of key operating parameters on decolorization and degradation by-products. Desalin. Water Treat. 2016, 57, 2616-2625. [CrossRef]

24. Devi, P.; Das, U.; Dalai, A.K. In-situ chemical oxidation: Principle and applications of peroxide and persulfate treatments in wastewater systems. Sci. Total Environ. 2016, 571, 643-657. [CrossRef]

25. Ghanbari, F.; Moradi, M.; Gohari, F. Degradation of 2,4,6-trichlorophenol in aqueous solutions using peroxymonosulfate/activated carbon/UV process via sulfate and hydroxyl radicals. J. Water Process. Eng. 2016, 9, 22-28. [CrossRef]

26. Ike, I.A.; Linden, K.G.; Orbell, J.D.; Duke, M. Critical review of the science and sustainability of persulphate advanced oxidation processes. Chem. Eng. J. 2018, 338, 651-669. [CrossRef]

27. Wacławek, S.; Lutze, H.V.; Grübel, K.; Padil, V.V.T.; Černík, M.; Dionysiou, D.D. Chemistry of persulfates in water and wastewater treatment: A review. Chem. Eng. J. 2017, 330, 44-62. [CrossRef]

28. Bekris, L.; Frontistis, Z.; Trakakis, G.; Sygellou, L.; Galiotis, C.; Mantzavinos, D. Graphene: A new activator of sodium persulfate for the advanced oxidation of parabens in water. Water Res. 2017, 126, 111-121. [CrossRef]

29. Frontistis, Z. Degradation of the nonsteroidal anti-inflammatory drug piroxicam from environmental matrices with UV-activated persulfate. J. Photochem. Photobiol. A Chem. 2019, 378, 17-23. [CrossRef] 
30. Frontistis, Z. Degradation of the Nonsteroidal Anti-Inflammatory Drug Piroxicam by Iron Activated Persulfate: The Role of Water Matrix and Ultrasound Synergy. Int. J. Environ. Res. Public Health 2018, 15, 2600. [CrossRef]

31. Ioannidi, A.; Frontistis, Z; Mantzavinos, D. Destruction of propyl paraben by persulfate activated with UV-A light emitting diodes. J. Environ. Chem. Eng. 2018, 6, 2992-2997. [CrossRef]

32. Frontistis, Z.; Mantzavinos, D. Advanced oxidation processes for wastewater treatment. In Wastewater and Biosolids Management; Kalavrouziotis, I.K., Ed.; IWA Publishing: London, UK, 2017; pp. 131-143.

33. Daskalaki, V.M.; Fulgione, I.; Frontistis, Z.; Rizzo, L.; Mantzavinos, D. Solar light-induced photoelectrocatalytic degradation of bisphenol-A on TiO2/ITO film anode and BDD cathode. Catal. Today 2013, 209, 74-78. [CrossRef]

34. Metheniti, M.E.; Frontistis, Z.; Ribeiro, R.S.; Silva, A.M.T.; Faria, J.L.; Gomes, H.T.; Mantzavinos, D. Degradation of propyl paraben by activated persulfate using iron-containing magnetic carbon xerogels: Investigation of water matrix and process synergy effects. Environ. Sci. Pollut. Res. 2018, 25, 34801-34810. [CrossRef] [PubMed]

35. Johnson, R.L.; Tratnyek, P.G.; Johnson, R.O. Persulfate Persistence under Thermal Activation Conditions. Environ. Sci. Technol. 2008, 42, 9350-9356. [CrossRef] [PubMed]

36. Deng, J.; Shao, Y.; Gao, N.; Deng, Y.; Zhou, S.; Hu, X. Thermally activated persulfate (TAP) oxidation of antiepileptic drug carbamazepine in water. Chem. Eng. J. 2013, 228, 765-771. [CrossRef]

37. Dewil, R.; Mantzavinos, D.; Poulios, I.; Rodrigo, M.A. New perspectives for Advanced Oxidation Processes. J. Environ. Manag. 2017, 195, 93-99. [CrossRef]

38. Pereira, V.J.; Weinberg, H.S.; Linden, K.G.; Singer, P.C. UV Degradation Kinetics and Modeling of Pharmaceutical Compounds in Laboratory Grade and Surface Water via Direct and Indirect Photolysis at 254 nm. Environ. Sci. Technol. 2007, 41, 1682-1688. [CrossRef]

39. Dimitrakopoulou, D.; Rethemiotaki, I.; Frontistis, Z.; Xekoukoulotakis, N.P.; Venieri, D.; Mantzavinos, D. Degradation, mineralization and antibiotic inactivation of amoxicillin by UV-A/TiO 2 photocatalysis. J. Environ. Manag. 2012, 98, 168-174. [CrossRef]

40. Michael, I.; Frontistis, Z.; Fatta-Kassinos, D. Removal of pharmaceuticals from environmentally relevant matrices by advanced oxidation processes (AOPs). In Comprehensive Analytical Chemistry; Elsevier BV: Amsterdam, The Netherlands, 2013; Volume 62, pp. 345-407.

41. Huang, K.C.; Zhao, Z.; Hoag, G.E.; Dahmani, A.; Block, P.A. Degradation of volatile organic compounds with thermally activated persulfate oxidation. Chemosphere 2005, 61, 551-560. [CrossRef]

42. Zhao, L.; Hou, H.; Fujii, A.; Hosomi, M.; Li, F. Degradation of 1,4-dioxane in water with heat- and $\mathrm{Fe}^{2+-}$ activated persulfate oxidation. Environ. Sci. Pollut. Res. 2014, 21, 7457-7465. [CrossRef]

43. Nie, M.; Yang, Y.; Zhang, Z.; Yan, C.; Wang, X.; Li, H.; Dong, W. Degradation of chloramphenicol by thermally activated persulfate in aqueous solution. Chem. Eng. J. 2014, 246, 373-382. [CrossRef]

44. Miranda, M.A.; Vargas, F.; Serrano, G. Photodegradation of piroxicam under aerobic conditions. The photochemical keys of the piroxicam enigma? J. Photochem. Photobiol. B Biol. 1991, 8, 199-202. [CrossRef]

45. Zhang, Q.; Chen, J.; Dai, C.; Zhang, Y.; Zhou, X. Degradation of carbamazepine and toxicity evaluation using the UV/persulfate process in aqueous solution. J. Chem. Technol. Biotechnol. 2015, 90, 701-708. [CrossRef]

46. Gao, Y.Q.; Gao, N.Y.; Deng, Y.; Yang, Y.Q.; Ma, Y. Ultraviolet (UV) light-activated persulfate oxidation of sulfamethazine in water. Chem. Eng. J. 2012, 195-196, 248-253. [CrossRef]

47. Wang, W.; Wang, H.; Li, G.; An, T.; Zhao, H.; Wong, P.K. Catalyst-free activation of persulfate by visible light for water disinfection: Efficiency and mechanisms. Water Res. 2019, 157, 106-118. [CrossRef]

48. Michael-Kordatou, I.; Michael, C.; Duan, X.; He, X.; Dionysiou, D.D.; Mills, M.A.; Fatta-Kassinos, D. Dissolved effluent organic matter: Characteristics and potential implications in wastewater treatment and reuse applications. Water Res. 2015, 77, 213-248. [CrossRef]

49. Ma, J.; Yang, Y.; Jiang, X.; Xie, Z.; Li, X.; Chen, C.; Chen, H. Impacts of inorganic anions and natural organic matter on thermally activated persulfate oxidation of BTEX in water. Chemosphere 2018, 190, $296-306$. [CrossRef]

50. Chen, Y.; Deng, P.; Xie, P.; Shang, R.; Wang, Z.; Wang, S. Heat-activated persulfate oxidation of methyl- and ethyl-parabens: Effect, kinetics, and mechanism. Chemosphere 2017, 168, 1628-1636. [CrossRef]

51. Bennedsen, L.R.; Muff, J.; Søgaard, E.G. Influence of chloride and carbonates on the reactivity of activated persulfate. Chemosphere 2012, 86, 1092-1097. [CrossRef] 
52. Kouskouki, A.; Chatzisymeon, E.; Mantzavinos, D.; Frontistis, Z. Electrochemical Degradation of Piroxicam on a Boron-Doped Diamond Anode: Investigation of Operating Parameters and Ultrasound Synergy. ChemElectroChem 2019, 6, 841-847. [CrossRef]

53. Outsiou, A.; Frontistis, Z.; Ribeiro, R.S.; Antonopoulou, M.; Konstantinou, I.K.; Silva, A.M.T.; Faria, J.L.; Gomes, H.T.; Mantzavinos, D. Activation of sodium persulfate by magnetic carbon xerogels (CX/CoFe) for the oxidation of bisphenol A: Process variables effects, matrix effects and reaction pathways. Water Res. 2017, 124, 97-107. [CrossRef] [PubMed]

54. Kanigaridou, Y.; Petala, A.; Frontistis, Z.; Antonopoulou, M.; Solakidou, M.; Konstantinou, I.; Deligiannakis, Y.; Mantzavinos, D.; Kondarides, D.I. Solar photocatalytic degradation of bisphenol A with CuOx/BiVO4: Insights into the unexpectedly favorable effect of bicarbonates. Chem. Eng. J. 2017, 318, 39-49. [CrossRef]

55. Lianou, A.; Frontistis, Z.; Chatzisymeon, E.; Antonopoulou, M.; Konstantinou, I.; Mantzavinos, D. Sonochemical oxidation of piroxicam drug: Effect of key operating parameters and degradation pathways. J. Chem. Technol. Biotechnol. 2018, 93, 28-34. [CrossRef]

56. McElroy, W.J. A laser photolysis study of the reaction of sulfate (1-) with chloride and the subsequent decay of chlorine(1-) in aqueous solution. J. Phys. Chem. 1990, 94, 2435-2441. [CrossRef]

57. Qi, C.; Liu, X.; Zhao, W.; Lin, C.; Ma, J.; Shi, W.; Sun, Q.; Xiao, H. Degradation and dechlorination of pentachlorophenol by microwave-activated persulfate. Environ. Sci. Pollut. Res. 2015, 22, 4670-4679. [CrossRef]

58. Lin, C.C.; Wu, M.S. Degradation of ciprofloxacin by UV/S2O82- process in a large photoreactor. J. Photochem. Photobiol. A Chem. 2014, 285, 1-6. [CrossRef]

(C) 2020 by the authors. Licensee MDPI, Basel, Switzerland. This article is an open access article distributed under the terms and conditions of the Creative Commons Attribution (CC BY) license (http://creativecommons.org/licenses/by/4.0/). 